\title{
Gaetbulimicrobium brevivitae gen. nov., sp. nov., a novel member of the family Flavobacteriaceae isolated from a tidal flat of the Yellow Sea in Korea
}

\author{
Jung-Hoon Yoon, So-Jung Kang, Seo-Youn Jung, Hyun Woo Oh \\ and Tae-Kwang Oh \\ Korea Research Institute of Bioscience and Biotechnology (KRIBB), PO Box 115, Yusong, \\ Taejon, Korea
}

Correspondence

Jung-Hoon Yoon

jhyoon@kribb.re.kr

\begin{abstract}
A Gram-negative, non-spore-forming and rod-shaped gliding bacterium, designated strain SMK $-19^{\top}$, was isolated from a tidal flat sediment of the Yellow Sea, Korea, and its taxonomic position was investigated by using a polyphasic approach. Strain SMK-19 $9^{\top}$ grew optimally at $37{ }^{\circ} \mathrm{C}$, in the presence of $2-3 \%(\mathrm{w} / \mathrm{V}) \mathrm{NaCl}$ and at $\mathrm{pH} 7 \cdot 0-8 \cdot 0$. It contained $\mathrm{MK}-6$ as the predominant menaquinone, and iso- $\mathrm{C}_{17: 0} 3-\mathrm{OH}$ and iso- $\mathrm{C}_{15: 0}$ as the major fatty acids. Major polar lipids were phosphatidylethanolamine, unidentified phospholipids and an amino-group-containing lipid that is ninhydrin-positive. The DNA G+C content was $36.0 \mathrm{~mol} \%$. Phylogenetic analyses based on 16S rRNA gene sequences demonstrated that strain SMK-19 ${ }^{\top}$ formed a distinct evolutionary lineage within the family Flavobacteriaceae. The 16S rRNA gene sequence of strain SMK $-19^{\top}$ exhibited similarity values of $<94 \cdot 4 \%$ to those of other members of the family Flavobacteriaceae. Strain SMK-19 ${ }^{\top}$ was distinguished from phylogenetically related genera by differences in several phenotypic properties. On the basis of phenotypic, phylogenetic and chemotaxonomic data, SMK $-19^{\top}\left(=\mathrm{KCTC} 12390^{\top}=\mathrm{DSM} 17196^{\top}\right)$ was classified at the type strain of a novel genus and species, Gaetbulimicrobium brevivitae gen. nov., sp. nov.
\end{abstract}

In recent years, many novel bacterial taxa have been isolated from a variety of regions of the west coast of the Korean peninsula (Yi et al., 2003, 2004; Yi \& Chun, 2004; Yoon et al., 2004, 2005a, b; Kim et al., 2005). In the course of screening novel micro-organisms from a tidal flat of Saemankum, on the Yellow Sea of Korea, many moderately halophilic or halotolerant bacteria have been isolated and characterized taxonomically. This study focuses on one of these isolates, designated strain SMK-19 ${ }^{\mathrm{T}}$. Comparative 16S rRNA gene sequence analysis indicated that strain SMK-19 ${ }^{\mathrm{T}}$ forms a deep branch within the family Flavobacteriaceae. Accordingly, the aim of the present work was to determine the exact taxonomic position of strain SMK $-19^{\mathrm{T}}$ by using a polyphasic characterization that included phenotypic properties and detailed phylogenetic analysis based on 16S rRNA gene sequences.

Tidal flat sediment collected from Saemankum, Pyunsan, Korea, provided the source for isolation of bacterial strains. Strain SMK-19 ${ }^{\mathrm{T}}$ was isolated by the standard dilution plating technique on marine agar 2216 (MA; Difco) at $30{ }^{\circ} \mathrm{C}$.

Published online ahead of print on 26 August 2005 as DOI 10.1099/ ijs.0.63795-0.

The GenBank/EMBL/DDBJ accession number for the 16S rRNA gene sequence of strain SMK-19 ${ }^{\top}$ is AY987367.
Cell morphology was examined by light microscopy (Nikon E600) and transmission electron microscopy. The presence of flagella was determined by transmission electron microscopy using cells at the exponential growth stage. Gliding motility was investigated as described by Bowman (2000). The Gram reaction was determined by using the bioMérieux Gram Stain kit according to the manufacturer's instructions. The $\mathrm{pH}$ range for growth was determined in marine broth 2216 (MB; Difco) that was adjusted to various $\mathrm{pH}$ values (initial $\mathrm{pH} 4 \cdot 5-10 \cdot 5$ at intervals of $0.5 \mathrm{pH}$ units). The $\mathrm{pH}$ was adjusted prior to sterilization to various levels by the addition of $\mathrm{HCl}$ or $\mathrm{Na}_{2} \mathrm{CO}_{3}$. Growth in the absence of $\mathrm{NaCl}$ was investigated in R2A agar (Difco) and trypticase soy broth prepared according to the formula for the Difco medium except that no $\mathrm{NaCl}$ was used. Growth at various $\mathrm{NaCl}$ concentrations was investigated in $\mathrm{MB}$ or trypticase soy broth. Growth at various temperatures $\left(4-45^{\circ} \mathrm{C}\right)$ was measured on MA. Growth under anaerobic conditions was determined after incubation in an anaerobic chamber on MA and on MA supplemented with nitrate, both of which had been prepared anaerobically using nitrogen. Catalase and oxidase activities and hydrolysis of casein and starch were determined as described by Cowan \& Steel (1965). Hydrolysis of Tweens 20, 40, 60 and 80 was determined as described by Cowan \& Steel (1965) with a modification that artificial sea water was used instead of distilled water. 
Hydrolysis of aesculin, gelatin and urea and nitrate reduction were determined as described by Lanyi (1987) with a modification that artificial sea water was used instead of distilled water. The artificial sea water contained (per litre distilled water) $23.6 \mathrm{~g} \mathrm{NaCl}, 0.64 \mathrm{~g} \mathrm{KCl}, 4.53 \mathrm{~g}$ $\mathrm{MgCl}_{2} \cdot 6 \mathrm{H}_{2} \mathrm{O}, 5.94 \mathrm{~g} \mathrm{MgSO}_{4} .7 \mathrm{H}_{2} \mathrm{O}$ and $1.3 \mathrm{~g} \mathrm{CaCl}_{2} \cdot 2 \mathrm{H}_{2} \mathrm{O}$ (Bruns et al., 2001). Hydrolysis of hypoxanthine, tyrosine and xanthine was investigated on MA with the substrate concentrations described by Cowan \& Steel (1965), i.e. 0•4, 0.5 and $0.4 \%(\mathrm{w} / \mathrm{V})$, respectively. $\mathrm{H}_{2} \mathrm{~S}$ production was tested as described by Bruns et al. (2001). Presence of flexirubin-type pigments was investigated as described by Reichenbach (1992). Freeze-dried cells were extracted with acetone/methanol $(1: 1, \mathrm{v} / \mathrm{v})$ to investigate the presence of carotenoids. Acid production from carbohydrates was determined as described by Leifson (1963). Utilization of substrates as sole carbon and energy sources was tested as described by Baumann \& Baumann (1981) using supplementation with $2 \%(\mathrm{v} / \mathrm{v})$ Hutner's mineral base (CohenBazire et al., 1957), 1 \% (v/v) vitamin solution (Staley, 1968)

Table 1. Differential phenotypic characteristics of Gaetbulimicrobium gen. nov. and related genera

Genera: 1, Gaetbulimicrobium gen. nov.; 2, Aquimarina (data from Nedashkovskaya et al., 2005a); 3, Stanierella (Reichenbach, 1989; Nedashkovskaya et al., 2005a); 4, Gillisia (Van Trappen et al., 2004; Nedashkovskaya et al., 2005c); 5, Salegentibacter (Nedashkovskaya et al., 2004, 2005b); 6, Mesonia (Nedashkovskaya et al., 2003); 7, Psychroflexus (Bowman et al., 1998; Donachie et al., 2004). All genera are positive for $\mathrm{NaCl}$ requirement (variable for Gillisia, Salegentibacter and Psychroflexus), alkaline phosphatase (not determined for Stanierella), oxidase (variable for Psychroflexus), hydrolysis of Tweens 20 and 40 (variable for Salegentibacter and not determined for Psychroflexus) and hydrolysis of gelatin and Tween 80 (variable for Psychroflexus). All genera are negative for urease (variable for Salegentibacter and Psychroflexus), nitrate reduction (variable for Salegentibacter and Psychroflexus) and acid production from D-glucose (variable for Gillisia, Salegentibacter and Psychroflexus). +, Positive; -, negative; ND, not determined; v, variable.

\begin{tabular}{|c|c|c|c|c|c|c|c|}
\hline Characteristic & 1 & 2 & 3 & 4 & 5 & 6 & 7 \\
\hline Catalase & + & + & - & + & + & + & + \\
\hline Gliding motility & + & + & - & - & - & - & $\mathrm{V}$ \\
\hline Pigmentation & Orange & $\begin{array}{c}\text { Dark yellow to } \\
\text { brown }\end{array}$ & Orange-red & Yellow & Yellow & Yellow & Orange \\
\hline Flexirubins & - & + & - & - & - & - & $-{ }^{\star}$ \\
\hline Growth at $>10 \% \mathrm{NaCl}$ & - & - & - & $\mathrm{V}$ & $\mathrm{V}$ & + & $\mathrm{V}$ \\
\hline Growth at $37^{\circ} \mathrm{C}$ & + & - & - & - & $\mathrm{V}$ & - & $\mathrm{V}$ \\
\hline $\mathrm{H}_{2} \mathrm{~S}$ production & - & - & + & - & + & + & $-{ }^{\star}$ \\
\hline$\beta$-Galactosidase & - & $\mathrm{ND}$ & + & $-\dagger$ & + & ND & $-{ }^{\star}$ \\
\hline \multicolumn{8}{|l|}{ Hydrolysis of: } \\
\hline Agar & - & - & + & - & - & - & $-{ }^{*}$ \\
\hline Casein & + & + & $+\ddagger$ & $\mathrm{V}$ & $\mathrm{V}$ & + & $\mathrm{V}$ \\
\hline Starch & + & + & - & - & + & - & $+^{*}$ \\
\hline \multicolumn{8}{|l|}{ Acid production from: } \\
\hline D-Cellobiose & + & - & - & - & - & - & - \\
\hline Maltose & - & - & - & - & + & - & $\mathrm{V}$ \\
\hline \multicolumn{8}{|l|}{ Utilization of: } \\
\hline D-Glucose & + & - & ND & + & + & - & ND \\
\hline D-Mannose & - & - & ND & - & + & - & $\mathrm{ND}$ \\
\hline Sucrose & - & - & ND & + & $\mathrm{V}$ & - & ND \\
\hline \multicolumn{8}{|l|}{ Susceptibility to: } \\
\hline Benzylpenicillin & + & - & - & - & + & ND & ND \\
\hline Carbenicillin & + & + & - & + & $\mathrm{V}$ & ND & ND \\
\hline Tetracycline & - & ND & ND & V & + & ND & ND \\
\hline $\begin{array}{l}\text { Major fatty acids } \$ \\
(>10 \% \text { of total })\end{array}$ & $\begin{array}{c}\mathrm{i}-\mathrm{C}_{17: 0} 3-\mathrm{OH}, \\
\mathrm{i}-\mathrm{C}_{15: 0}\end{array}$ & $\begin{array}{c}\mathrm{i}-\mathrm{C}_{17: 0} 3-\mathrm{OH}, \\
\mathrm{i}-\mathrm{C}_{15: 0}, \mathrm{i}-\mathrm{C}_{15: 1}, \\
\mathrm{i}-\mathrm{C}_{17: 1} \omega 9 c\end{array}$ & $\begin{array}{c}\mathrm{i}-\mathrm{C}_{17: 0} 3-\mathrm{OH}, \\
\mathrm{i}-\mathrm{C}_{15: 0} \\
\mathrm{i}-\mathrm{C}_{17: 1} \omega 7 c\end{array}$ & $\begin{array}{c}\mathrm{C}_{17: 0} 2-\mathrm{OH} \\
\text { or } \mathrm{i}-\mathrm{C}_{15: 1}\end{array}$ & $\begin{array}{c}\mathrm{i}-\mathrm{C}_{15: 0}, \mathrm{i}-\mathrm{C}_{15: 1} \\
\mathrm{C}_{16: 1} \omega 7 c \\
\text { or } \mathrm{i}-\mathrm{C}_{15: 1}\end{array}$ & $\begin{array}{c}\mathrm{i}-\mathrm{C}_{15: 0}, \mathrm{i}-\mathrm{C}_{17: 0} \\
3-\mathrm{OH}\end{array}$ & $\begin{array}{c}\text { ai- } \mathrm{C}_{15: 0}, \\
\text { ai- } \mathrm{C}_{15: 1} \omega 10 c, \\
\mathrm{i}-\mathrm{C}_{16: 0} 3-\mathrm{OH}\end{array}$ \\
\hline $\begin{array}{l}\text { DNA G+C content } \\
(\mathrm{mol} \%)\end{array}$ & $36 \cdot 0$ & $31 \cdot 6-32 \cdot 5$ & 34 & $36-39$ & 37-38 & $32 \cdot 7-34 \cdot 0$ & $32-36$ \\
\hline
\end{tabular}

${ }^{*}$ Data for Psychroflexus torquis and Psychroflexus gondwanensis.

$\dagger$ Data for Gillisia limnaea.

¥Data taken from Nedashkovskaya et al. (2005a); the opposite result was reported by Reichenbach (1989).

§Abbreviations: i, iso; ai, anteiso. Data for the genus Salegentibacter were taken from Salegentibacter holothuriorum and Salegentibacter mishustinae. 
and $0.005 \%(\mathrm{w} / \mathrm{v})$ yeast extract. Susceptibility to antibiotics was tested on MA plates using discs containing the following antibiotics: polymyxin B (100 U), streptomycin $(50 \mu \mathrm{g})$, penicillin $\mathrm{G}(20 \mathrm{U})$, chloramphenicol $(100 \mu \mathrm{g})$, ampicillin $(10 \mu \mathrm{g})$, cephalothin $(30 \mu \mathrm{g})$, gentamicin $(30 \mu \mathrm{g})$, novobiocin $(5 \mu \mathrm{g})$, tetracycline $(30 \mu \mathrm{g})$, kanamycin $(30 \mu \mathrm{g})$, lincomycin $(15 \mu \mathrm{g})$, oleandomycin $(15 \mu \mathrm{g})$, neomycin $(30 \mu \mathrm{g})$ or carbenicillin $(100 \mu \mathrm{g})$. Other physiological and biochemical tests were performed with the API ZYM and API 20E systems (bioMérieux); cell suspension to inoculate the systems was prepared by using cells cultivated for 2 days at $37^{\circ} \mathrm{C}$ on MA and artificial sea water (Bruns et al., 2001).

Cell biomass of strain SMK- $19^{\mathrm{T}}$ for DNA extraction and for isoprenoid quinone and polar lipid analyses was obtained by cultivation for 2 days in $\mathrm{MB}$ at $37^{\circ} \mathrm{C}$. Chromosomal DNA was isolated and purified according to the method described previously (Yoon et al., 1996), with the exception that RNase T1 was used in combination with RNase A to minimize contamination with RNA. The 16S rRNA gene was amplified by PCR using two universal primers as described previously (Yoon et al., 1998). Sequencing of the amplified 16S rRNA gene and phylogenetic analysis were performed as described by Yoon et al. (2003). Isoprenoid quinones were extracted according to the method of Komagata \& Suzuki (1987) and analysed using reversed-phase HPLC and a YMC ODS-A $(250 \times 4.6 \mathrm{~mm})$ column. For fatty acid methyl ester analysis, cell mass of strain SMK $-19^{\mathrm{T}}$ was harvested from agar plates after incubation for 3 days on MA at $30^{\circ} \mathrm{C}$. The fatty acid methyl esters were extracted and prepared according to the standard protocol of the MIDI/Hewlett Packard Microbial Identification System (Sasser, 1990). The DNA G + C content was determined by the method of Tamaoka \& Komagata (1984) with a modification that DNA was hydrolysed and the resulting nucleotides were analysed by reversed-phase HPLC.

Morphological, cultural, physiological and biochemical characteristics of strain SMK- $19^{\mathrm{T}}$ are given in the species description (see below) or are detailed in Table 1, together with those of several phylogenetically related genera. The almost complete $16 \mathrm{~S}$ rRNA gene sequence of strain SMK-19 was determined, comprising $1480 \mathrm{nt}$ (approximately $96 \%$ of the Escherichia coli 16S rRNA gene sequence). Phylogenetic trees based on $16 \mathrm{~S}$ rRNA gene sequences showed that strain SMK- $19^{\mathrm{T}}$ forms a distinct phylogenetic lineage within the family Flavobacteriaceae (Fig. 1). In phylogenetic trees based on the neighbour-joining and maximum-likelihood algorithms, strain SMK- $19^{\mathrm{T}}$ joined the phylogenetic clade comprising the genera Aquimarina and Stanierella, with which it exhibited the highest 16S rRNA gene sequence similarity values $(94 \cdot 0-94 \cdot 4 \%)$; its sequence similarity values with the other species used in the phylogenetic analysis were lower (e.g. 92.6\% with Gillisia limnaea) (Fig. 1).

The predominant isoprenoid quinone detected in strain SMK-19 ${ }^{\mathrm{T}}$ was menaquinone- 6 (MK-6) at a peak area ratio of approximately $94 \%$. Strain SMK- $19^{\mathrm{T}}$ contained large amounts of branched, hydroxy, straight-chain and unsaturated fatty acids; components making up $\geqslant 1 \%$ of the total were iso- $\mathrm{C}_{17: 0} 3-\mathrm{OH}(31.9 \%)$, iso- $\mathrm{C}_{15: 0}(20 \cdot 2 \%)$, iso- $\mathrm{C}_{15: 0}$ 3-OH (6.9\%), iso- $\mathrm{C}_{15: 1}(5 \cdot 2 \%), \mathrm{C}_{15: 0}(4 \cdot 5 \%)$, iso- $\mathrm{C}_{16: 0}$ $(4 \cdot 0 \%)$, unknown fatty acids $(3 \cdot 9 \%$, sum of ECLs $11 \cdot 543$, 13.565 and 16.582), iso- $\mathrm{C}_{15: 0} 2-\mathrm{OH}$ and/or $\mathrm{C}_{16: 1} \omega 7 c(3 \cdot 7 \%)$, iso- $\mathrm{C}_{17: 1} \omega 9 c(3 \cdot 7 \%)$, iso- $\mathrm{C}_{16: 0} 3-\mathrm{OH}(2 \cdot 9 \%), \mathrm{C}_{17: 1} \omega 6 c$ $(1 \cdot 4 \%)$, iso- $\mathrm{C}_{16: 1}(1 \cdot 4 \%)$, iso- $\mathrm{C}_{14: 0}(1 \cdot 3 \%), \mathrm{C}_{16: 0}(1 \cdot 2 \%)$ and $\mathrm{C}_{17: 0} 3-\mathrm{OH}(1 \cdot 0 \%)$. Phosphatidylethanolamine was the only phospholipid identified in strain SMK- $19^{\mathrm{T}}$, and other major polar lipids were three unidentified phospholipids and an amino-group-containing lipid that was ninhydrin-positive. The DNA G + C content of strain SMK- $19^{\mathrm{T}}$ was $36 \cdot 0 \mathrm{~mol} \%$.

Strain SMK $-19^{\mathrm{T}}$ could be differentiated from its closest phylogenetic neighbours in the family Flavobacteriaceae based on the phenotypic properties listed in Table 1. It is noteworthy that growth of strain SMK- $19^{\mathrm{T}}$ persisted for a short period only (approximately $4-5$ days on MA at $37^{\circ} \mathrm{C}$ ). Acetone/methanol extract of the freeze-dried cells showed absorption maxima at 474 and $505 \mathrm{~nm}$, demonstrating the

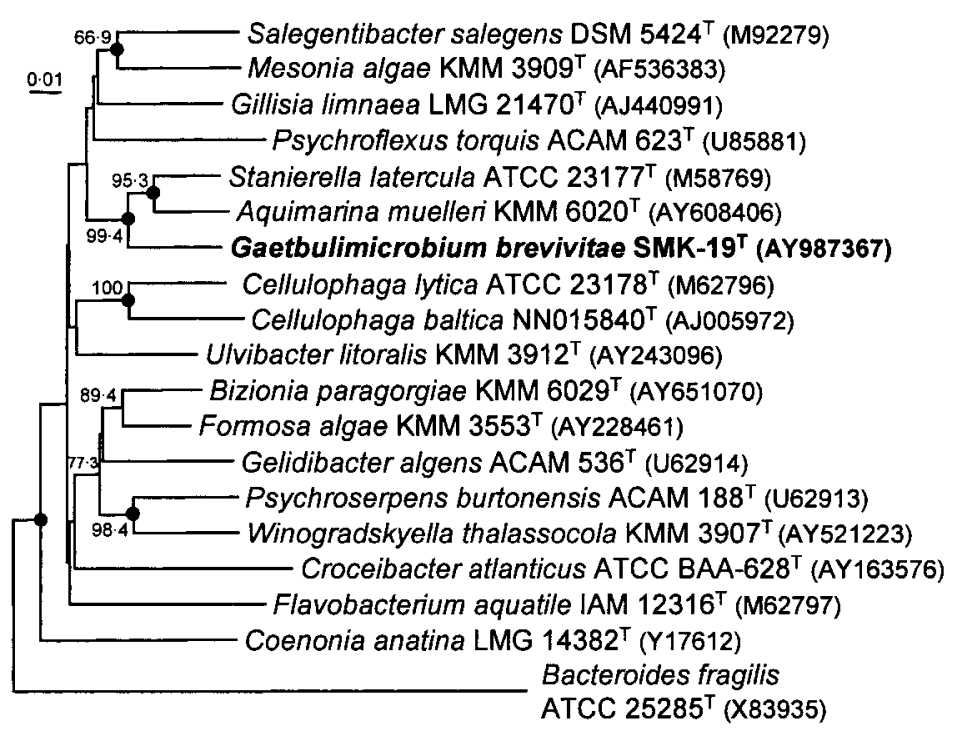

Fig. 1. Neighbour-joining tree based on $16 S$ rRNA gene sequences showing the phylogenetic positions of strain SMK-19 $9^{\top}$ and representatives of some other related taxa. Bootstrap values (expressed as percentages of 1000 replications) $>50 \%$ are shown at the branch points. Bacteroides fragilis ATCC $25285^{\top}$ was used as an outgroup. Dots indicate that the corresponding nodes are also recovered in the tree generated with the maximum-likelihood algorithm. Bar, 0.01 substitutions per nucleotide position. 
presence of carotenoids. The nature and concentration of the major fatty acids also helped to differentiate strain SMK$19^{\mathrm{T}}$ from the members of related genera (Table 1), although these differences may result in part from the use of different culture conditions. On the basis of the phenotypic and phylogenetic data presented, we propose the creation of a novel genus and species in the family Flavobacteriaceae, Gaetbulimicrobium brevivitae gen. nov., sp. nov., to accommodate strain SMK-19 ${ }^{\mathrm{T}}$.

\section{Description of Gaetbulimicrobium gen. nov.}

Gaetbulimicrobium (Gaet.bu.li.mi.cro'bi.um. N.L. n. gaetbulum $-i$ gaetbul, the Korean name for a tidal flat; N.L. neut. n. microbium a microbe; N.L. neut. n. Gaetbulimicrobium a microbe isolated from a tidal flat).

Cells are Gram-negative, non-spore-forming, non-flagellated and rod-shaped. Strictly aerobic. The predominant menaquinone is MK-6. Major polar lipids are phosphatidylethanolamine, unidentified phospholipids and an aminogroup-containing lipid that is ninhydrin-positive. The type species is Gaetbulimicrobium brevivitae.

\section{Description of Gaetbulimicrobium brevivitae sp. nov.}

Gaetbulimicrobium brevivitae (bre.vi.vi'tae. L. adj. brevis short; L. gen. n. vitae of life; N.L. gen. n. brevivitae of a short life, referring to the short-lived cultures of the type strain).

Exhibits the following properties in addition to those given in the genus description. Cells are rods, $0 \cdot 2-0 \cdot 3 \times 1 \cdot 0$ $15.0 \mu \mathrm{m}$, motile by gliding. Colonies on MA are circular to irregular, slightly raised, smooth, orange-coloured and $1 \cdot 0-2 \cdot 0 \mathrm{~mm}$ in diameter after incubation for 2 days at $37^{\circ} \mathrm{C}$. Carotenoid pigments are produced. Growth occurs at 10 and $41{ }^{\circ} \mathrm{C}$ with an optimum temperature of $37^{\circ} \mathrm{C}$; growth does not occur at 4 or $42^{\circ} \mathrm{C}$. Optimal pH for growth is $7 \cdot 0-8 \cdot 0$; growth is observed at $\mathrm{pH} 5 \cdot 5$ but not at $\mathrm{pH} 5 \cdot 0$. Optimal growth occurs in the presence of $2-3 \%(\mathrm{w} / \mathrm{v}) \mathrm{NaCl}$; growth does not occur in the absence of $\mathrm{NaCl}$ and in the presence of $>10 \%(\mathrm{w} / \mathrm{v}) \mathrm{NaCl}$. Aesculin, hypoxanthine, Tween 60 and tyrosine are hydrolysed, but xanthine is not. Indole is not produced. Acetone/methanol extract shows absorption maxima at 474 and $505 \mathrm{~nm}$. Arginine dihydrolase, lysine decarboxylase, ornithine decarboxylase and tryptophan deaminase are absent. In assays with the API ZYM system, esterase (C4), esterase lipase (C8), leucine arylamidase, valine arylamidase, acid phosphatase and naphthol-AS-BI-phosphohydrolase are present and $\beta$ glucosidase is weakly present, but lipase (C14), cystine arylamidase, trypsin, $\alpha$-chymotrypsin, $\alpha$-galactosidase, $\beta$ glucuronidase, $\alpha$-glucosidase, $N$-acetyl- $\beta$-glucosaminidase, $\alpha$-mannosidase and $\alpha$-fucosidase are absent. Maltose and pyruvate are utilized, but D-fructose, D-galactose, Dcellobiose, D-trehalose, D-xylose, L-arabinose, acetate, citrate, succinate, benzoate, L-malate, salicin, formate and L-glutamate are not utilized. Acid is not produced from L-arabinose, D-fructose, D-galactose, lactose, D-mannose,
D-melezitose, melibiose, D-raffinose, L-rhamnose, D-ribose, sucrose, D-trehalose, D-xylose, myo-inositol, D-mannitol or D-sorbitol. Susceptible to ampicillin, cephalothin, chloramphenicol, novobiocin, lincomycin, streptomycin and oleandomycin, but not to gentamicin, kanamycin, polymyxin $\mathrm{B}$ or neomycin. The major fatty acids are iso- $\mathrm{C}_{17: 0} 3-\mathrm{OH}$ $(31.9 \%)$ and iso- $\mathrm{C}_{15: 0}(20 \cdot 2 \%)$. The DNA G $+\mathrm{C}$ content is $36.0 \mathrm{~mol} \%$. Other characteristics are detailed in Table 1.

The type strain, SMK- $19^{\mathrm{T}}\left(=\mathrm{KCTC} 12390^{\mathrm{T}}=\mathrm{DSM} 17196^{\mathrm{T}}\right)$, was isolated from a tidal flat sediment at Saemankum, Pyunsan, Korea.

\section{Acknowledgements}

This work was supported by the 21C Frontier programme of Microbial Genomics and Applications (grant MG02-0401-001-1-0-0) from the Ministry of Science and Technology (MOST) of the Republic of Korea. We are grateful to Professor Hans Trüper for help with nomenclature of the novel species.

\section{References}

Baumann, P. \& Baumann, L. (1981). The marine Gram-negative eubacteria: genera Photobacterium, Beneckea, Alteromonas, Pseudomonas, and Alcaligenes. In The Prokaryotes, pp. 1302-1331. Edited by M. P. Starr, H. Stolp, H. G. Trüper, A. Balows \& H. G. Schlegel. Berlin: Springer.

Bowman, J. P. (2000). Description of Cellulophaga algicola sp. nov., isolated from the surfaces of Antarctic algae, and reclassification of Cytophaga uliginosa (ZoBell and Upham 1944) Reichenbach 1989 as Cellulophaga uliginosa comb. nov. Int J Syst Evol Microbiol 50, 1861-1868.

Bowman, J. P., McCammon, S. A., Lewis, T., Skerratt, J. H., Brown, J. L., Nichols, D. S. \& McMeekin, T. A. (1998). Psychroflexus torquis gen. nov., sp. nov., a psychrophilic species from Antarctic sea ice, and reclassification of Flavobacterium gondwanense (Dobson et al. 1993) as Psychroflexus gondwanense gen. nov., comb. nov. Microbiology 144, 1601-1609.

Bruns, A., Rohde, M. \& Berthe-Corti, L. (2001). Muricauda ruestringensis gen. nov., sp. nov., a facultatively anaerobic, appendaged bacterium from German North Sea intertidal sediment. Int J Syst Evol Microbiol 51, 1997-2006.

Cohen-Bazire, G., Sistrom, W. R. \& Stanier, R. Y. (1957). Kinetic studies of pigment synthesis by nonsulfur purple bacteria. J Cell Comp Physiol 49, 25-68.

Cowan, S. T. \& Steel, K. J. (1965). Manual for the Identification of Medical Bacteria. London: Cambridge University Press.

Donachie, S. P., Bowman, J. P. \& Alam, M. (2004). Psychroflexus tropicus sp. nov., an obligately halophilic Cytophaga-FlavobacteriumBacteroides group bacterium from an Hawaiian hypersaline lake. Int J Syst Evol Microbiol 54, 935-940.

Kim, I.-G., Lee, M.-H., Jung, S.-Y., Song, J. J., Oh, T.-K. \& Yoon, J.-H. (2005). Exiguobacterium aestuarii sp. nov. and Exiguobacterium marinum sp. nov., isolated from a tidal flat of the Yellow Sea in Korea. Int J Syst Evol Microbiol 55, 885-889.

Komagata, K. \& Suzuki, K. (1987). Lipids and cell-wall analysis in bacterial systematics. Methods Microbiol 19, 161-203.

Lanyi, B. (1987). Classical and rapid identification methods for medically important bacteria. Methods Microbiol 19, 1-67. 
Leifson, E. (1963). Determination of carbohydrate metabolism of marine bacteria. J Bacteriol 85, 1183-1184.

Nedashkovskaya, O. I., Kim, S. B., Han, S. K. \& 7 other authors (2003). Mesonia algae gen. nov., sp. nov., a novel marine bacterium of the family Flavobacteriaceae isolated from the green alga Acrosiphonia sonderi (Kütz) Kornm. Int J Syst Evol Microbiol 53, 1967-1971.

Nedashkovskaya, O. I., Suzuki, M., Vancanneyt, M., Cleenwerck, I., Zhukova, N. V., Vysotskii, M. V., Mikhailov, V. V. \& Swings, J. (2004). Salegentibacter holothuriorum sp. nov., isolated from the edible holothurian Apostichopus japonicus. Int J Syst Evol Microbiol 54, 1107-1110.

Nedashkovskaya, O. I., Kim, S. B., Lysenko, A. M., Frolova, G. M., Mikhailov, V. V., Lee, K. H. \& Bae, K. S. (2005a). Description of Aquimarina muelleri gen. nov., sp. nov., and proposal of the reclassification of [Cytophaga] latercula Lewin 1969 as Stanierella latercula gen. nov., comb. nov. Int J Syst Evol Microbiol 55, 225-229.

Nedashkovskaya, O. I., Kim, S. B., Lysenko, A. M., Mikhailov, V. V., Bae, K. S. \& Kim, I. S. (2005b). Salegentibacter mishustinae sp. nov., isolated from the sea urchin Strongylocentrotus intermedius. Int J Syst Evol Microbiol 55, 235-238.

Nedashkovskaya, O. I., Kim, S. B., Lee, K. H., Mikhailov, V. V. \& Bae, K. S. (2005c). Gillisia mitskevichiae sp. nov., a novel bacterium of the family Flavobacteriaceae, isolated from sea water. Int J Syst Evol Microbiol 55, 321-323.

Reichenbach, H. (1989). Genus Cytophaga Winogradsky 1929, $577^{\mathrm{AL}}$. In Bergey's Manual of Systematic Bacteriology, vol. 3, pp. 2015-2050. Edited by J. T. Staley, M. P. Bryant, N. Pfennig \& J. C. Holt. Baltimore: Williams \& Wilkins.

Reichenbach, H. (1992). The order Cytophagales. In The Prokaryotes. A Handbook on the Biology of Bacteria: Ecophysiology, Isolation, Identification, Applications, 2nd edn, pp. 3631-3675. Edited by A. Balows, H. G. Trüper, M. Dworkin, W. Harder \& K. H. Schleifer. New York: Springer.

Sasser, M. (1990). Identification of bacteria by gas chromatography of cellular fatty acids. Newark, DE: MIDI Inc.

Staley, J. T. (1968). Prosthecomicrobium and Ancalomicrobium: new prosthecate freshwater bacteria. J Bacteriol 95, 1921-1942.
Tamaoka, J. \& Komagata, K. (1984). Determination of DNA base composition by reverse-phase high-performance liquid chromatography. FEMS Microbiol Lett 25, 125-128.

Van Trappen, S., Vandecandelaere, I., Mergaert, J. \& Swings, J. (2004). Gillisia limnaea gen. nov., sp. nov., a new member of the family Flavobacteriaceae isolated from a microbial mat in Lake Fryxell, Antarctica. Int J Syst Evol Microbiol 54, 445-448.

Yi, H. \& Chun, J. (2004). Nocardioides ganghwensis sp. nov., isolated from tidal flat sediment. Int J Syst Evol Microbiol 54, 1295-1299.

Yi, H., Chang, Y.-H., Oh, H. W., Bae, K. S. \& Chun, J. (2003). Zooshikella ganghwensis gen. nov., sp. nov., isolated from tidal flat sediments. Int J Syst Evol Microbiol 53, 1013-1018.

Yi, H., Bae, K. S. \& Chun, J. (2004). Aestuariibacter salexigens gen. nov., sp. nov. and Aestuariibacter halophilus sp. nov., isolated from tidal flat sediment, and emended description of Alteromonas macleodii. Int J Syst Evol Microbiol 54, 571-576.

Yoon, J.-H., Kim, H., Kim, S.-B., Kim, H.-J., Kim, W. Y., Lee, S. T., Goodfellow, M. \& Park, Y.-H. (1996). Identification of Saccharomonospora strains by the use of genomic DNA fragments and rRNA gene probes. Int J Syst Bacteriol 46, 502-505.

Yoon, J.-H., Lee, S. T. \& Park, Y.-H. (1998). Inter- and intraspecific phylogenetic analysis of the genus Nocardioides and related taxa based on 16S rRNA gene sequences. Int J Syst Bacteriol 48, 187-194.

Yoon, J.-H., Kang, K. H. \& Park, Y.-H. (2003). Psychrobacter jeotgali sp. nov., isolated from jeotgal, a traditional Korean fermented seafood. Int J Syst Evol Microbiol 53, 449-454.

Yoon, J.-H., Oh, T.-K. \& Park, Y.-H. (2004). Kangiella koreensis gen. nov., sp. nov. and Kangiella aquimarina sp. nov., isolated from a tidal flat of the Yellow Sea in Korea. Int J Syst Evol Microbiol 54, 1829-1835.

Yoon, J.-H., Oh, T.-K. \& Park, Y.-H. (2005a). Erythrobacter seohaensis sp. nov. and Erythrobacter gaetbuli sp. nov., isolated from a tidal flat of the Yellow Sea in Korea. Int J Syst Evol Microbiol 55, 71-75.

Yoon, J.-H., Kang, S.-J. \& Oh, T.-K. (2005b). Tenacibaculum lutimaris sp. nov., isolated from a tidal flat in the Yellow Sea, Korea. Int J Syst Evol Microbiol 55, 793-798. 